\title{
Properties of New Strawberry Lines Compared with Well-Known Cultivars in Winter Planting System Conditions
}

\author{
Leo SABATINO ${ }^{1}$, Claudio DE PASQUALE ${ }^{1 *}$, Farid ABOUD ${ }^{1}$, \\ Federico MARTINELLI ${ }^{1}$, Matteo BUSCONI², Eleonora D'ANNA ${ }^{1}$, \\ Stefano PANNO ${ }^{1}$, Giovanni IAPICHINO ${ }^{1}$, Fabio D’ANNA ${ }^{1}$
}

\author{
${ }^{1}$ Università degli Studi di Palermo, Dipartimento di Scienze Agrarie e Forestali, Viale delle Scienze, 90128, Palermo, Italy; \\ leo.sabatino@unipa.it; claudio.depasquale@unipa.it (*correspondingauthor); abboudfarid@yahoo.fr;federico.martinelli@unipa.it; \\ eleonora.danna@unipa.it;panno.stefano@unipa.it; giovani.iapichino@unipa.it;fabio.danna@unipa.it \\ ${ }^{2}$ Università Cattolica S.C., Dipartimento di Scienze delle Produzioni Vegetali Sostenibili, \\ ViaEmilia Parmense, 29122, Piacenza, Italy; matteo.busconi@unicatt.it
}

\begin{abstract}
In Southern Italy and Sicily, strawberry cultivation is dominated by international cultivars such as 'Candonga Sabrosa', 'Florida Fortuna', 'Sabrina' and 'Sant Andreas'. The primary objective of our study was to compare the field performance of two experimental lines and four established cultivars in a Sicilian representative strawberry production area. The second objective was to compare the fruits physic-chemical nutraceutical characteristics of these genotypes in response to different postharvest fruit storage temperatures. A supporting genetic analysis, via SSR markers, was also performed in order to establish genotype correlations. Our study confirmed the high result of 'Florida Fortuna' in terms of earliness and productivity and the high performance of 'Candonga Sabrosa' in terms of total soluble content and fruit firmness. The new lines 'PA1' and 'PA2' showed satisfying results. However, the new line 'PA2', might deserve particular attention by growers involved in strawberry early fruit production in Mediterranean areas both for its yield performance and fruit quality characteristics. This study also showed that a $4{ }^{\circ} \mathrm{C}$ fruit storage temperature treatment for 36 hours positively affects the physical and chemical quality properties of strawberry fruits, whereas overall quality declines at $20^{\circ} \mathrm{C}$ storage. According to the genetic characterization, 'PA2' was closely related to 'Candonga Sabrosa' and 'Florida Fortuna'.
\end{abstract}

Keywords: antioxidant properties, early production, Fragaria $\times$ ananassa Duch., strawberry fruit colour, storage conditions

\section{Introduction}

The cultivated strawberry Fragaria $\times$ ananassa Duch. $(2 n$ $=8 x=56)$ is an economically important fruit crop belonging to the Rosaceae family, with a worldwide production of 4,516,810 tonnes and a Gross Production Value of 10,745 million dollars (USD) in 2012 (FAOSTAT, 2012). United States of America represents the first producer of strawberry (1,934,361 tonnes) followed by Europe (1,316,950 tonnes). Spain is the first producer in Europe (289,900 tonnes), while Italy showed a production of 40,858 tonnes distributed in 1,981 Ha, with a Gross Production Value of 116 million dollars (USD) in 2012 (FAOSTAT, 2012). The genus Fragaria consists of approximately 20 wild species with a basic chromosome number $x=7$. Four ploidy levels were present: diploid, tetraploid, hexaploid and octoploid (Hancock, 1999). Fragaria $\times$ ananassa Duch. is a results of hybridisation between two native American species, F. chiloensis $(\mathrm{L})$ Duch. $(2 n=56)$ and F. viriginiana Duch. $(2 n=56)$. Retrospective evaluations of genetic progress are common for agronomic crops, and productivity gains of $0.5-2.0 \%$ per year are generally reported (Duvic, 1977; Russell, 1984; Troyer, 1990). Progress in crop plant productivity is generally due by changes in the cultural environment, in genetics, and by their interaction, and the success of strawberry crop in Sicily is an example of these effects (D’Anna and Iapichino, 2002).

In Southern Italy and Sicily, strawberry cultivation is dominated by international varieties such as 'Candonga Sabrosa', 'Florida Fortuna', 'Sabrina', and 'Sant Andreas'. Sicily differs from other strawberry production areas for earlier fruit 
ripening. This earliness is enhanced by the use of fresh plants, which, compared to the cold-stored plants used in the past, have expanded the harvest window from December to May, and provided fruits of higher quality (D'Anna et al., 2009; D'Anna et al., 2014). As enhanced research efforts are nowadays needed to increase Sicilian grower profits, field testing new cultivars with high yield performance and improved fruit quality characteristics and the application of novel cultural techniques represent a powerful tool to expand cultivar selection, extend the growing season and assure an increased availability of the crop for consumers (Cocco et al., 2015; Miceli et al., 2014). Therefore, the first objective of our study was to compare the field performance of two experimental lines and four established cultivars in a Sicilian representative strawberry production area.

Strawberry fruits are popular with consumers, but marketing is limited by a short shelf-life. The possibility to extend the postharvest life by storage at low temperatures has been assessed (Harris and Harvey; 1973; Larsen and Watkins, 1995; Mercantilia, 1989, Smith, 1992). Therefore, the second objective was to compare the physic-chemical nutraceutical characteristics of the fruits of two experimental strawberry lines and four established cultivars in response to different postharvest fruit storage temperatures $\left(20\right.$ or $\left.4^{\circ} \mathrm{C}\right)$ for 36 hours before commercialization. Characterization is a reliable tool for breeding improvement of horticultural crops (Shaw and Larson, 2008; D'Anna and Sabatino, 2013; Sabatino et al., 2013). Therefore, a supporting genetic analysis, via SSR markers, was also performed in order to establish genotype correlations.

\section{Materials and Methods}

The research was conducted for two years (2013 and 2014) in an experimental field at Marsala (long. $12^{\circ} 26^{\prime} \mathrm{E}$, lat. $37^{\circ} 47^{\prime} \mathrm{N}$ ) in the North-western coast of Sicily (Italy). According to the first objective of this study, a set of six strawberry genotypes [two new selected lines, ('PA1' and 'PA2') and four wellknown cultivars adopted in Southern Italy ('Candonga Sabrosa', 'Florida Fortuna', 'Sabrina' and 'Sant Andreas')] (Fig. 1) were compared. All genotypes were transplanted by using the conventional winter planting system for protected cultivation (D'Anna et al., 2005). The trials were carried out under multiple tunnels in soil deriving from transformation of the typically fertile Sicilian 'sciare' soils, mainly made up of sand $(<80 \%)$ at $\mathrm{pH} 8.5$, high activity limestone at $8.8 \%$ and richly endowed with exchangeable $\mathrm{K}_{2} \mathrm{O}$ (660 ppm), phosphorous (68 $\mathrm{ppm})$, total nitrogen $(2 \% \mathrm{o})$ and organic matter from the annual $10 \mathrm{t} / \mathrm{ha}$ intake of exhausted distillery marc. The soil was subjected yearly to geo-disinfestation via drip fumigation using a mix of chloropicrin $\left(20 \mathrm{~g} / \mathrm{m}^{2}\right)+1,3$ dicloropropene $(20$ $\left.\mathrm{g} / \mathrm{m}^{2}\right)$ supplied 30 days before transplanting and, in summer, was ploughed, levelled and raised; the resulting beds were mulched with green polyethylene (PE) film under which a micro-ranged irrigation system was placed. Freshly containerized plants were transplanted on 20 September 2013 and 2014 in twin rows at a density of 8 plants $\mathrm{m}^{-2}$. All cultural practices recommended for strawberry cultivation were adopted uniformly according to crop requirements. Fertilization was applied with drip irrigation throughout the growing cycle. Fifteen fertilization treatments were supplied an overall $200 \mathrm{~kg} / \mathrm{ha}$ of $\mathrm{N}, 150$ of $\mathrm{P}_{2} \mathrm{O}_{5}, 300$ of $\mathrm{K}_{2} \mathrm{O}$ and 60 of iron chelate. The tunnels were covered in the second half of November with $120 \mu \mathrm{m}$ thick clear PE plus EVA. The six genotypes were tested in a randomized block design with four replicates per treatment. Each treatment consisted of 20 plants of each genotype (plot size of $250 \times 100 \mathrm{~cm}$ ). All necessary cultural practices and plant protection measures were followed uniformly for all the plots during the entire trial period. Fruit yield data was recorded on all harvest dates. Monthly and total fruit yield was calculated by taking all the harvested fruit on each picking and thereafter, fruit which were free from malformation and Botrytis rot symptoms were sorted out to calculate the marketable fruit yield. All data were subjected to analysis of variance (ANOVA) and mean separation was performed by Duncan multiple range test. Data obtained were statistically analyzed using SPSS software version 14.0 (StatSoft, Inc., Chicago, USA).

According to the second objective of this study, we tested the fruit physic-chemical nutraceutical characteristics of two experimental strawberry lines and four established cultivars in response to different postharvest fruit storage temperatures. Commercially mature fruits were harvested according to fruit dimension, colour and glossiness. Immediately after harvesting 10 fruits per replication and genotype from the January harvest were subjected to 20 or $4{ }^{\circ} \mathrm{C}$ for 36 hours into a climatic chamber (Model T; Biemme s.a.s.; Rome; Italy). The experiment was defined by a factorial combination of six genotypes $(G)$ and two fruit storage conditions $(S)$ (20 or $\left.4{ }^{\circ} \mathrm{C}\right)$. A randomized block experimental design with four replicates per treatment was adopted. A two-way fixed-effects general linear model analysis of variance (ANOVA) was used to determine the effects of different genotypes and storage conditions. Mean separation was performed by Duncan multiple range test. Percentages were subjected to angular transformation prior to perform statistical analysis $(\Phi=$ $\left.\arcsin (\mathrm{p} / 100)^{1 / 2}\right)$. Data obtained were statistically analyzed using SPSS software version 14.0 (StatSoft, Inc., Chicago, USA).
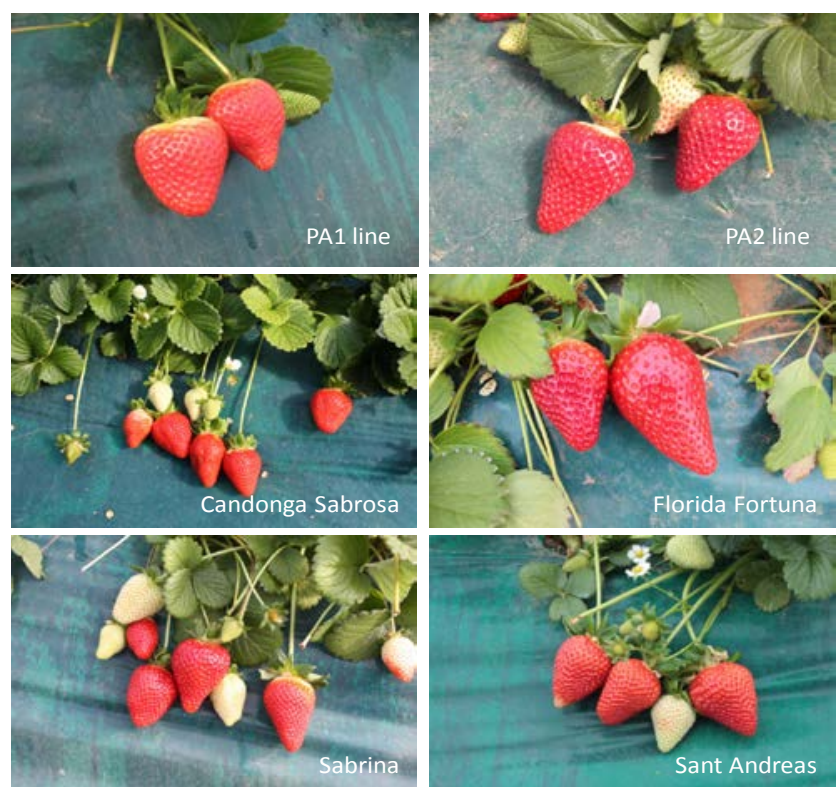

Fig. 1. Strawberry fruits of the tested genotypes 
Quality characteristics of strawberry fruit were measured in 10 representative commercially mature fruit for each replicate. Colour ( $\mathrm{L}^{*} \mathrm{a}^{*}$, and $\mathrm{b}^{*}$ parameters - CIELab) was measured on two opposite point of strawberry fruit skin (equatorial zone) by a colorimeter (Chroma-meter CR-400, Minolta Corporation, Ltd., Osaka, Japan). Chroma $\left(\mathrm{C}^{*}\right)$ and Hue angle $\left(\mathrm{H}^{\circ}\right)$ were also calculated as follows: $\mathrm{C}^{*}=\left(\mathrm{a}^{2}+\mathrm{b}^{2}\right)^{1 / 2}, \mathrm{H}^{\circ}=\arctan \left(\mathrm{b}^{*} / \mathrm{a}^{*}\right)$. The colorimeter was also used to determine the lightness of fruit pulp by measuring $\mathrm{L}^{*}$ value $(0=$ black and $100=$ white $)$. Berry firmness was determined by measuring its resistance to the plunger of a digital penetrometer (Trsnc, Italy). Each fruit was subjected to a compression in the equatorial part using a 6 $\mathrm{mm}$ diameter stainless steel cylinder probe. The mean peak force was calculated in Newton (N). Sample of the fruit pulp were squeezed by hand with a garlic squeezer. The juice was filtered and soluble solids content (SSC) was measured using a digital refractometer (MTD-045nD, Three-In-One Enterprises Co. Ltd. Taiwan). Titratable acidity (TA) was determined using $10 \mathrm{~g}$ aliquots of strawberry fruits poured in $50 \mathrm{ml}$ of distilled water and titrated with $0.1 \mathrm{~N} \mathrm{NaOH}$ to an end-point of $\mathrm{pH}$ 8.1. TA was expressed as percentage of citric acid and was calculated using the method reported by Han $e t$ al., 2004.

Ascorbic acid content was measured from strawberry samples of each genotype by reflectometer Merck RQflex* 10 meter using Reflectoquant Ascorbic Acid Test Strips. One gram of fruit juice were dissolved in distilled water, maked up to $10 \mathrm{~mL}$, and mixed. Then dipped appropriate test strip into the sample and inserted it into the meter. Results were expressed as $\mathrm{mg}$ of ascorbic acid per L fresh weigh. Total anthocyanins were determined by using the fruit extract which was prepared by an established procedure as described by Rabino and Mancinell (1986). About $2 \mathrm{~g}$ (triplicate) of each sample was weighed out and extracted with $50 \mathrm{ml}$ of solvent containing hydrochloric acid ethanol mixture (95\% ethanol, $1.5 \mathrm{~N} \mathrm{HCl}(85 / 15))$, the mixture was stored overnight at $4{ }^{\circ} \mathrm{C}$, then filtered out using Whatman No. 3 filter paper. After extraction of anthocyanins with acidified ethanol, the absorbance of the extracts was measured using a spectrophotometer (CELL, model CE 1020) at 530 and $657 \mathrm{~nm}$. Using formula $\mathrm{A}=(\mathrm{A} 530-0.25 \mathrm{~A} 657)$ to compensate the contribution of chlorophyll and its degraded products to the absorption at $530 \mathrm{~nm}$. The anthocyanin content was expressed as mg of Cya-3-glucoside equivalent per $100 \mathrm{~g}$ of dry sample weight.

Determination of total phenolics was measured by using 2 $\mathrm{g}$ of each sample was weighed out and extracted with $50 \mathrm{ml}$ of methanol. The extraction was carried out under stirring for 60 $\min$ at $60{ }^{\circ} \mathrm{C}$. The mixture was filtered through filter paper (Whatman No. 3), filled in a $50 \mathrm{ml}$ volumetric flask and allowed to set in the dark until analysis. Total phenolic content was determined according to the Folin-Ciocalteu (FC) method (Slinkard and Singleton, 1997) with slight modifications. The standard or sample extract $(100 \mu \mathrm{L})$ (triplicate) was mixed with $0.4 \mathrm{~mL}$ FC reagent. After 3 minutes reaction $0.8 \mathrm{~mL}$ of $10 \% \mathrm{Na}_{2} \mathrm{CO}_{3}$ was added. The tubes were allowed to stand for 30 minutes at ambient temperature, and the absorption was measured at $765 \mathrm{~nm}$ using a spectrophotometer (CELL, model CE 1020). Gallic acid was used as calibration standard, and the results were calculated as gallic acid equivalent (GAE) (mg/100 g dry weight basis). Radical-scavenging activity of 1,1-diphenyl-2-picrylhydrazyl radical (DPPH) of fruit samples was measured in terms of their radical-scavenging ability (RSA), using the DPPH method (Brand-Williams et al., 1995; Sorrenti et al., 2006). Aliquots of the whole strawberry juice were mixed with an ethanol solution of DPPH ( $3 \mathrm{mM})$, namely $2.37 \mathrm{mg}$ DPPH in $2 \mathrm{~mL}$ ethanol. For the sample solution, $28 \mu \mathrm{L}$ whole juices were mixed with $28 \mu \mathrm{L} \mathrm{DPPH}$ solutions and $944 \mu \mathrm{L}$ ethanol. After incubation in the dark at room temperature for $10 \mathrm{~min}$, the spectrophotometric determination was assayed at $515 \mathrm{~nm}$ using a spectrophotometer (CELL, model CE 1020). A freshly prepared DPPH blank solution (containing $972 \mu \mathrm{L}$ ethanol and $28 \mu \mathrm{L}$ DPPH solution) was used. The DPPH solution was stored in a flask covered with aluminium foil, and kept in the dark at $4{ }^{\circ} \mathrm{C}$ between measurements. The percentage decrease in absorbance was recorded for each sample, and percentage quenching of DPPH radical was calculated on the basis of the observed decrease in absorbance according to the formula: \% Inhibition $=\left[\left(A_{0}-A_{1}\right) / A_{0}\right] \times 100$ where $A_{0}$ is the absorbance value of the DPPH blank solution and $A_{1}$ is the absorbance value of the sample solution.

In order to perform the genetic analysis, DNA was extracted using the DNeasy Plant Mini Kit. (Qiagen, Germany). The DNA quality and concentration of the extracted DNA was measured with the NanoDrop ND-1000 (NanoDrop Technologies Inc., USA). The final DNA concentration was adjusted to $20 \mathrm{ng} / \mu \mathrm{L}$ for PCR reactions. To perform the simple sequence repeat (SSR) analysis a total of five different SSR markers were chosen from Yoon et al. (2012). PCR amplification reactions were performed in a total volume of $20 \mu \mathrm{L}$ including $20 \mathrm{ng}$ genomic DNA, $2 \mu \mathrm{M}$ of the specific forward and reverse primers, $1 \times$ PCR buffer, $0.2 \mathrm{mM}$ dNTP, and $0.5 \mathrm{U}$ Taq polymerase. Conditions of the PCR amplification were the following: $94^{\circ} \mathrm{C}(3 \mathrm{~min}), 30$ cycles at 94 ${ }^{\circ} \mathrm{C}(30 \mathrm{sec}), 60^{\circ} \mathrm{C}(45 \mathrm{sec})$, and $72^{\circ} \mathrm{C}(45 \mathrm{sec})$, followed by 20 cycles at $94^{\circ} \mathrm{C}(30 \mathrm{sec}), 53^{\circ} \mathrm{C}(45 \mathrm{sec}), 72^{\circ} \mathrm{C}(45 \mathrm{sec})$, and a final extension at $72{ }^{\circ} \mathrm{C}$ for $20 \mathrm{~min}$. The amplified products from SSR amplifications were visualized in an ABI Prism 3100 Genetic Analyzer (Life Technologies) using the GeneScan Analysis software (Life Technologies). The electrophoretic patterns were visually inspected. The visible band of each genotype was recorded as binary data: $1=$ presence of fragment and $0=$ absence of fragment.

Genetic similarity among samples was evaluated by estimating the Jaccard coefficient. In order to generate a dendrogram evidencing the relationships of the different genotypes, a cluster analyses was carried out by using the unweighted pair group method average (UPGMA) method (NTSYS-pc2.11a software). The cophenetic correlation coefficient was calculated and Mantel's test was performed (1000 permutation) (data not shown) to check the goodness of fit of the cluster analysis to the matrix on which it was based.

\section{Results and Discussion}

\section{Field experiment}

Fruit production began in middle December and continued through middle April (Table 1). Marketable fruit production by the end of January was significantly influenced by the genotypes tested. 'Florida Fortuna' gave the highest yield (123.3 $\left.\mathrm{g} \mathrm{plant}^{-1}\right)$, followed by 'PA2' line (92.7 $\left.\mathrm{g} \mathrm{plant}^{-1}\right)$. Early yields were significantly lower in 'Sabrina', 'PAl', and 'Sant Andreas' whereas 'Candonga Sabrosa' exhibited the lowest figures (11.7 $\left.\mathrm{g} \mathrm{plant}^{-1}\right)$. 
12

As regard the February harvest, 'Sant Andreas' cultivar gave the highest production per plant $(166.4 \mathrm{~g})$, followed by 'Florida Fortuna' and 'Sabrina' (132.0 and 130.0 g plant $^{-1}$, respectively). The line 'PA2' showed a lower fruit production compared to the January harvest. As regard as marketable fruit production by March, 'Candonga Sabrosa' and 'PA2' line exhibited significantly higher yields (228.7 and 226.0 g plant ${ }^{-1}$, respectively) than the other genotypes tested, whereas 'Sant Andreas' showed the lowest production (146.5 g plant $\left.^{-1}\right)$. Fruit production by April was highest in 'PA1' and 'PA2' lines (238.0 and $218.7 \mathrm{~g}$ plant $^{-1}$, respectively), and lowest in 'Candonga Sabrosa' (120.7 g plant $^{-1}$ ).

Data recorded on total marketable fruit production almost paralleled data recorded on early yields (January harvest) with 'Florida Fortuna' giving the highest production (653.3 g plant' $\left.{ }^{1}\right)$, followed by 'PA2' line $\left(604.4 \mathrm{~g} \mathrm{plant}^{-1}\right)$ which in turn gave higher yields than 'PA1' (573.9 $\left.\mathrm{g} \mathrm{plant}^{-1}\right)$ and 'Sabrina' $(519.9 \mathrm{~g}$ plant $\left.^{-1}\right)$.

These results confirm that 'Florida Fortuna' is a cultivar particularly suitable for early yields in the Mediterranean environment. However the 'PA2' line produced data which allowed us to form a highly positive opinion on its potential use by Sicilian strawberry growers.

\section{Fruit quality experiment}

Total soluble solids (TSS) was significantly influenced by the genotypes tested. Regardless of the storage fruit treatment, 'Candonga Sabrosa' and 'Sabrina' showed the highest values (10.3 and 8.8 Brix $^{\circ}$, respectively), whereas 'PA2' line exhibited the lowest TSS content $\left(6.3\right.$ Brix $\left.^{\circ}\right)$ (Tables 2 and 3 ). Regardless of the genotype tested, TSS content in strawberry fruits stored at $4{ }^{\circ} \mathrm{C}$ resulted significantly higher than in those stored at 20 ${ }^{\circ} \mathrm{C}$. No significant interaction was found between $\mathrm{G}$ and $\mathrm{S}$ in terms of TSS (Table 2). Strawberry fruits are highly perishable (Han et al., 2005), consequently, low storage temperature may help in extending fruit shelf life to some extent (Manning, 1996). The significant TSS loss recorded at $20{ }^{\circ} \mathrm{C}$ storage temperature may be attributed to an enhanced respiration rate. Our results are similar to those reported by Gil et al. (1997) and Pelayo et al. (2003).

The genotypes tested showed statistical differences in their titratable acidity (TA); regardless of the storage fruit treatment, the highest value was recorded in 'Sant Andreas' ( $0.7 \%$ of citric acid), followed by 'PA2' ( $0.6 \%$ of citric acid). According to ANOVA results, TA was not affected by the storage treatment and no significant interaction was detected between $G$ and $S$ treatments. Besides their importance in flavour, acids are important in processing because they affect the gelling properties of pectin. Citric acid is a major constitutes of the acids in strawberry and it contributes to $92 \%$ of acidity

Table 1. Effects of strawberry genotype on monthly and total marketable fruit production

\begin{tabular}{|c|c|c|c|c|c|c|c|c|c|c|}
\hline \multirow{3}{*}{$\frac{\text { Genotype }}{\text { 'PA1' }}$} & \multicolumn{8}{|c|}{ Monthly marketable production $\left(\mathrm{g} \mathrm{plant}^{-1}\right)$} & \multirow{2}{*}{\multicolumn{2}{|c|}{ Total }} \\
\hline & \multicolumn{2}{|c|}{ Jan } & \multicolumn{2}{|c|}{ Feb } & \multicolumn{2}{|c|}{ Mar } & \multicolumn{2}{|c|}{ Apr } & & \\
\hline & 21.3 & $\mathrm{~d}$ & 111.3 & c & 203.3 & $\mathrm{~b}$ & 238.0 & $\mathrm{a}$ & 573.9 & c \\
\hline 'PA2' & 92.7 & b & 67.0 & e & 226.0 & a & 218.7 & $a b$ & 604.4 & b \\
\hline 'Candonga Sabrosa’ & 11.7 & f & 80.7 & $\mathrm{~d}$ & 228.7 & a & 172.7 & c & 493.8 & e \\
\hline 'Florida Fortuna' & 123.3 & a & 132.0 & b & 210.0 & b & 188.0 & c & 653.3 & a \\
\hline 'Sabrina’' & 32.3 & c & 130.0 & b & 163.3 & c & 194.3 & $\mathrm{bc}$ & 519.9 & d \\
\hline 'Sant Andreas' & 17.3 & $\mathrm{e}$ & 166.4 & $\mathrm{a}$ & 146.5 & d & 120.7 & d & 450.9 & $\mathrm{f}$ \\
\hline
\end{tabular}

followed by malic acid 9\% (Green, 1971). Our results are not in agreement with those obtained by Pelayo et al. (2003) and Cordenunsi (2003) who reported an increase in acidity of strawberries during storage. These differences might be related to the different genotypes tested.

Regardless of the storage fruit treatment, ascorbic acid (AA) content differed significantly among genotypes, with the greatest figure in 'PA2' $\left(61.0 \mathrm{mg} \cdot \mathrm{L}^{-1}\right)$ and the lowest in 'Candonga Sabrosa' cultivar (45.2 mg. $\left.\mathrm{L}^{-1}\right)$ (Table 2 and Table 3 ). Regardless of the genotype tested, the AA content in strawberry fruits stored at $4{ }^{\circ} \mathrm{C}$ resulted significantly higher than in those stored at $20{ }^{\circ} \mathrm{C}$.ANOVA for AA showed a significant effect of the interaction $\mathrm{G} \times \mathrm{S}$. With the exception of the combination 'Candonga Sabrosa' $\times$ fruit storage at $4{ }^{\circ} \mathrm{C}$, AA content was significantly higher in 'Sant Andreas', 'PA1', 'PA2', 'Sabrina' and 'Florida Fortuna' fruits stored at $4{ }^{\circ} \mathrm{C}$ $\left(73.3,67.7,63.7,62.3\right.$, and $60 . \mathrm{mg} \cdot \mathrm{L}^{-1}$, respectively) than in the fruits of the respective genotypes stored at $20^{\circ} \mathrm{C}(45.0,50.3$, 58.3, 44.0, and $36.0 \mathrm{mg} \cdot \mathrm{L}^{-1}$, respectively). Ascorbic acid is known for its beneficial effects on human health and also being highly unstable it is an indication of fruit freshness (Sanz et al., 1999).

Data for anthocyanin content of new lines ('PAl' and 'PA2') and established cultivars are presented in Tables 2 and 3. Regardless of the fruit storage temperature, 'Florida Fortuna' gave the highest anthocyanin content (106.6 mg of Cya-3glucoside per $100 \mathrm{~g}$ ) followed by 'Sabrina', 'Candonga Sabrosa' and 'PAl' (86.3, 81.7, 70.9 mg of Cya-3-glucoside per $100 \mathrm{~g}$, respectively) which in turn showed a higher content than 'Sant Andreas' and 'PA2' (63.9 and 53. mg of Cya-3-glucoside per $100 \mathrm{~g}$, respectively). Regardless of the genotypes tested, fruit storage at $4{ }^{\circ} \mathrm{C}$ for 36 hours resulted in a significantly higher anthocyanin content as compared to fruit storage at $20^{\circ} \mathrm{C}$ (95.3 and $59.1 \mathrm{mg}$ of Cya-3-glucoside per $100 \mathrm{~g}$, respectively). Anthocyanin pigments have demonstrated ability to protect against several human diseases (Lila, 2004). No significant interaction for anthocyanin content was detected between $G$ and $S$.

As regard as total phenolic content, regardless of the storage temperature treatment, 'Candonga Sabrosa' showed the highest figure ( $\left.519.8 \mathrm{mg} 100 \mathrm{~g}^{-1}\right)$ followed by 'Sant Andreas', 'Sabrina', and 'PA1', whereas the lowest amount was detected

Table 2. Results of analysis of variance for fruit quality characteristics for the genotype study $(\mathrm{G})$ and for the storage treatment study $(S)$

\begin{tabular}{|c|c|c|c|}
\hline \multirow{2}{*}{ Parameter } & \multicolumn{3}{|c|}{ Significance } \\
\hline & G & $S$ & $\mathrm{G} \times \mathrm{S}$ \\
\hline Total soluble solid $\left(\right.$ Brix $\left.^{\circ}\right)$ & *** & *** & NS \\
\hline Titratable acidity (\% of citric acid) & *** & NS & NS \\
\hline Ascorbic acid $\left(\mathrm{mg} \mathrm{L}^{-1}\right)$ & *** & $* * *$ & $* * *$ \\
\hline Antocyanin (mg of Cya-3-glucoside per $100 \mathrm{~g}$ ) & *** & *** & NS \\
\hline 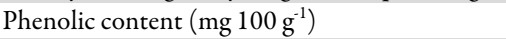 & *** & *** & *** \\
\hline Antioxidant capacity (\% inhibition) & *** & *** & *** \\
\hline$a^{*}$ & *** & *** & NS \\
\hline $\mathrm{b}^{*}$ & *** & *** & *** \\
\hline $\mathrm{L}^{*}$ & *** & *** & NS \\
\hline Chroma & *** & *** & NS \\
\hline $\mathrm{Hue}^{\circ}$ & *** & *** & $* * *$ \\
\hline Firmness (N) & $* * *$ & $* * *$ & $*$ \\
\hline \multicolumn{4}{|c|}{$\begin{array}{l}\text { The significance is designated by asterisks as follows: }{ }^{*} \text { statistically significant } \\
\text { differences at P-value below } 0.05 ;{ }^{* *} \text { statistically significant differences at P- } \\
\text { value below } 0.01 ;{ }^{* * *} \text { statistically significant differences at P-value below } \\
0.001 \text {. NS = not significant }\end{array}$} \\
\hline
\end{tabular}


Table 3. Effect of genotype $(G)$ and fruit storage treatment $(S)$ on total soluble solid, titratable acidity, ascorbic acid, antocyanin, phenolic content antioxidant capacity, $\mathrm{a}^{*}, \mathrm{~b}^{*}, \mathrm{~L}^{*}$, Chroma, Hue colour parameters and firmness of two experimental lines and four established cultivars in a Sicilian representative strawberry production area

\begin{tabular}{|c|c|c|c|c|c|c|c|c|}
\hline \multirow[b]{2}{*}{ Parameter } & \multicolumn{6}{|c|}{ G } & \multicolumn{2}{|c|}{$S$} \\
\hline & 'PA1' & 'PA2' & $\begin{array}{l}\text { 'Candonga } \\
\text { Sabrosa' }\end{array}$ & $\begin{array}{l}\text { 'Florida } \\
\text { Fortuna' }\end{array}$ & 'Sabrina' & $\begin{array}{c}\text { 'Sant } \\
\text { Andreas' }\end{array}$ & $\begin{array}{c}36 \text { hours at } \\
4^{\circ} \mathrm{C}\end{array}$ & $\begin{array}{c}36 \text { hours at } \\
20^{\circ} \mathrm{C}\end{array}$ \\
\hline Total soluble solid $\left(\right.$ Brix $\left.^{\circ}\right)$ & $7.2 \mathrm{bc}$ & $6.3 c$ & $10.3 \mathrm{a}$ & $7.2 \mathrm{bc}$ & $8.8 \mathrm{ab}$ & $8.2 \mathrm{~b}$ & $8.7 \mathrm{a}$ & $7.3 \mathrm{~b}$ \\
\hline Titratable acidity (\% of citric acid) & $0.4 \mathrm{bc}$ & $0.6 \mathrm{~b}$ & $0.5 \mathrm{bc}$ & $0.5 \mathrm{bc}$ & $0.3 \mathrm{c}$ & $0.7 \mathrm{a}$ & $0.5 \mathrm{NS}$ & $0.5 \mathrm{NS}$ \\
\hline Ascorbic acid $\left(\mathrm{mg} \mathrm{L}^{-1}\right)$ & $59.0 \mathrm{a}$ & $61.0 \mathrm{a}$ & $45.2 \mathrm{c}$ & $48.2 \mathrm{bc}$ & $53.2 \mathrm{~b}$ & $59.2 \mathrm{a}$ & $63.6 \mathrm{a}$ & $44.9 \mathrm{~b}$ \\
\hline Antocyanin (mg of Cya-3-glucoside per $100 \mathrm{~g}$ ) & $70.9 \mathrm{bcd}$ & $53.8 \mathrm{~d}$ & $81.7 \mathrm{bc}$ & $106.6 \mathrm{a}$ & $86.3 \mathrm{~b}$ & $63.9 \mathrm{~cd}$ & $95.3 \mathrm{a}$ & $59.1 \mathrm{~b}$ \\
\hline 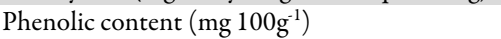 & $483.8 \mathrm{ab}$ & $406.2 \mathrm{c}$ & $519.8 \mathrm{a}$ & $472.5 \mathrm{~b}$ & $488.5 \mathrm{ab}$ & $511.2 \mathrm{ab}$ & $503.1 \mathrm{a}$ & $457.6 \mathrm{~b}$ \\
\hline Antioxidant capacity (\% inhibition) & $77.0 \mathrm{bc}$ & $78.3 \mathrm{bc}$ & $81.6 b$ & $88.1 \mathrm{a}$ & $81.4 \mathrm{~b}$ & $73.7 \mathrm{c}$ & $83.7 \mathrm{a}$ & $76.4 b$ \\
\hline $\mathrm{a}^{*}$ & $40.0 \mathrm{bc}$ & $40.6 \mathrm{~b}$ & $41.3 \mathrm{a}$ & $39.5 \mathrm{c}$ & $40.5 \mathrm{~b}$ & $37.7 \mathrm{~d}$ & $40.5 \mathrm{a}$ & $39.4 b$ \\
\hline$b^{*}$ & $20.2 c$ & $20.7 \mathrm{c}$ & $20.3 c$ & $22.9 \mathrm{a}$ & $23.3 \mathrm{a}$ & $22.2 \mathrm{~b}$ & $21.2 \mathrm{~b}$ & $22.0 \mathrm{a}$ \\
\hline $\mathrm{L}^{*}$ & $39.3 \mathrm{a}$ & $38.6 \mathrm{~b}$ & $39.6 \mathrm{a}$ & $37.8 \mathrm{c}$ & $37.1 \mathrm{~d}$ & $36.8 \mathrm{~d}$ & $39.0 \mathrm{a}$ & $37.4 \mathrm{~b}$ \\
\hline Chroma & $44.8 \mathrm{c}$ & $45.6 \mathrm{~b}$ & $46.0 \mathrm{~b}$ & $45.7 \mathrm{~b}$ & $46.8 \mathrm{a}$ & $43.8 \mathrm{~d}$ & $45.8 \mathrm{a}$ & $45.1 \mathrm{~b}$ \\
\hline $\mathrm{Hue}^{\circ}$ & $0.47 \mathrm{~b}$ & $0.47 \mathrm{~b}$ & $0.46 \mathrm{~b}$ & $0.53 \mathrm{a}$ & $0.52 \mathrm{a}$ & $0.53 \mathrm{a}$ & $0.48 \mathrm{~b}$ & $0.51 \mathrm{a}$ \\
\hline Firmness (N) & $7.4 \mathrm{c}$ & $8.2 \mathrm{~b}$ & $8.8 \mathrm{a}$ & $8.1 \mathrm{~b}$ & $7.4 \mathrm{c}$ & $6.2 \mathrm{~d}$ & $7.6 \mathrm{a}$ & $7.4 \mathrm{~b}$ \\
\hline
\end{tabular}

Results indicate mean value of two years (2013 and 2014). Different letters in rows denote significant differences in treatment at $\mathrm{P} \leq 0.001$ according to Duncan Multiple Range Test.

Table 4. Effects of the interaction genotype $(G) \times$ fruit storage treatment $(S)$ on ascorbic acid, phenolic content, antioxidant capacity, b*, $\mathrm{Hue}^{\circ}$ colour parameters and firmness of two experimental lines and four established cultivars in a Sicilian representative strawberry production area

\begin{tabular}{|c|c|c|c|c|c|c|c|c|c|c|c|c|}
\hline \multirow{2}{*}{ Parameter } & \multicolumn{12}{|c|}{ Interaction $(\mathrm{G} \times \mathrm{S})$} \\
\hline & $\mathrm{G} 1 \times \mathrm{S} 1$ & $\mathrm{G} 1 \times \mathrm{S} 2$ & $\mathrm{G} 2 \times \mathrm{S} 1$ & $\mathrm{G} 2 \times \mathrm{S} 2$ & $\mathrm{G} 3 \times \mathrm{S} 1$ & $\mathrm{G} 3 \times \mathrm{S} 2$ & $\mathrm{G} 4 \times \mathrm{S} 1$ & $\mathrm{G} 4 \times \mathrm{S} 2$ & $\mathrm{G} 5 \times \mathrm{S} 1$ & $\mathrm{G} 5 \times \mathrm{S} 2$ & $\mathrm{G} 6 \times \mathrm{S} 1$ & $\mathrm{G} 6 \times \mathrm{S} 2$ \\
\hline Ascorbic acid $\left(\mathrm{mgL}^{-1}\right)$ & $67.7 \mathrm{ab}$ & $50.3 c$ & $63.7 \mathrm{ab}$ & $58.3 \mathrm{~b}$ & $54.3 c$ & $36.0 \mathrm{~d}$ & $60.3 \mathrm{~b}$ & $36.0 \mathrm{~d}$ & $62.3 \mathrm{ab}$ & $44.0 \mathrm{~cd}$ & $73.3 \mathrm{a}$ & $45.0 \mathrm{~cd}$ \\
\hline Phenolic content $\left(\mathrm{mg} 100 \mathrm{~g}^{-1}\right)$ & $522.0 \mathrm{ab}$ & $445.7 \mathrm{c}$ & $482.5 b$ & $330.0 \mathrm{~d}$ & $540.7 a$ & $499.0 \mathrm{ab}$ & $469.0 \mathrm{~b}$ & $476.0 \mathrm{~b}$ & $505.3 \mathrm{ab}$ & $471.7 b$ & $499.0 \mathrm{ab}$ & $523.3 \mathrm{ab}$ \\
\hline Antioxidant capacity (\% inhibition) & $73.2 c$ & $80.8 \mathrm{bc}$ & $88.4 \mathrm{a}$ & $68.2 \mathrm{~d}$ & $84.0 \mathrm{~b}$ & $79.3 \mathrm{bc}$ & $92.0 \mathrm{a}$ & $84.2 b$ & $76.7 \mathrm{c}$ & $86.2 b$ & $87.9 \mathrm{ab}$ & $59.5 \mathrm{e}$ \\
\hline$b^{*}$ & $19.0 \mathrm{~d}$ & $21.5 b c$ & $20.5 c$ & $20.9 c$ & $21.2 \mathrm{bc}$ & $19.3 \mathrm{~d}$ & $22.4 \mathrm{~b}$ & $23.5 \mathrm{a}$ & $22.8 \mathrm{~b}$ & $23.7 \mathrm{a}$ & $21.6 b c$ & $23.0 \mathrm{ab}$ \\
\hline $\mathrm{Hue}^{\circ}$ & $0.44 \mathrm{~d}$ & $0.50 \mathrm{~b}$ & $0.46 c$ & $0.48 b c$ & $0.47 \mathrm{c}$ & $0.44 \mathrm{~d}$ & $0.51 \mathrm{~b}$ & $0.54 a$ & $0.51 \mathrm{~b}$ & $0.54 a$ & $0.51 \mathrm{~b}$ & $0.55 \mathrm{a}$ \\
\hline Firmness $(\mathrm{N})$ & $7.2 \mathrm{~d}$ & $7.6 \mathrm{c}$ & $8.1 \mathrm{~b}$ & $8.2 \mathrm{~b}$ & $8.7 \mathrm{ab}$ & $8.8 \mathrm{a}$ & $7.9 \mathrm{bc}$ & $8.2 \mathrm{~b}$ & $7.2 \mathrm{~d}$ & $7.5 c$ & $6.1 \mathrm{f}$ & $6.4 \mathrm{e}$ \\
\hline
\end{tabular}

Results indicate mean value of two years (2013 and 2014). Different letters in rows denote significant differences in treatment according to Duncan Multiple Range Test. G1 = 'PA1'; G2 = 'PA2'; G3 =

'CandongaSabrosa'; G4= 'Florida Fortuna'; G5 = 'Sabrina'; G6 = 'Sant Andreas'. $1=4{ }^{\circ} \mathrm{C} ; \mathrm{S} 2=20^{\circ} \mathrm{C}$

in 'PA2'. Regardless of the genotypes tested, total phenolic content in strawberry fruits stored at $4{ }^{\circ} \mathrm{C}$ resulted significantly higher than in those stored at $20^{\circ} \mathrm{C}$. ANOVA for phenolic content showed a significant effect of the interaction $\mathrm{G} \times \mathrm{S}$ (Tables 2 and 4) with the highest figure in the combination 'Candonga Sabrosa' $\times$ fruit storage at $4{ }^{\circ} \mathrm{C}$ and the lowest in the combination 'PA2' $\times$ fruit storage at $20^{\circ} \mathrm{C}$. However, fruit storage at $4{ }^{\circ} \mathrm{C}$ significantly increased total phenolic compounds in 'PA1', 'PA2', but not in the established cultivars as compared to fruit storage at $20^{\circ} \mathrm{C}$. With the exception of the combinations 'Florida Fortuna' $\times$ fruit storage at $4{ }^{\circ} \mathrm{C}$ and 'Sant Andreas' $\times$ fruit storage at $4{ }^{\circ} \mathrm{C}$, total phenolic compounds were significantly higher in 'Candonga Sabrosa', 'PA1', 'Sabrina', 'PA2' fruits stored at $4{ }^{\circ} \mathrm{C}$ than in the fruits of the respective genotypes stored at $20^{\circ} \mathrm{C}$. Our results are in accord with those obtained by (Wang et al., 2012). Increase in the total phenols in fruits stored at $4^{\circ} \mathrm{C}$ have been related to the hydrolysis of the tannins (Foo and Porter, 1981). Healthbeneficial effects due to fruit phenolic content in fruits have been stressed by Tomás-Barberan and Espin (2001).

The effects of free radical scavenging of DPPH are presented in Tables 2, 3 and 4. Regardless of the storage temperature treatment, all strawberry genotypes showed significant differences in terms of antioxidant activity ranging from 73.7\% ('Sant Andreas') to 88.1\% ('Florida Fortuna').

The antioxidant capacity in fruits stored at $4{ }^{\circ} \mathrm{C}(83.7 \%)$, averaged over genotypes was significantly higher than in fruits stored at $20{ }^{\circ} \mathrm{C}(76.4 \%)$. ANOVA showed a significant interaction of $\mathrm{G} \times \mathrm{S}$. 'Florida Fortuna' and 'PAl' fruits stored at $4^{\circ} \mathrm{C}$ showed the highest antioxidant capacity followed by the combination 'Sant Andreas' $\times$ fruit storage at $44^{\circ} \mathrm{C}$. The lowest antioxidant capacity was detected in 'PA2' fruits stored at $20^{\circ} \mathrm{C}$. Our results are in agreement with those of Wicklund $e t$ al. (2005) who reported a reduction of antioxidant activity and anthocyanin content in strawberry stored at $20^{\circ} \mathrm{C}$. According to Patthamakanokporn et al. (2008), this reduction is due to phenolics degradation. Among the factors that can influence the levels of antioxidant activity and total phenolic compounds, temperature was found to be a fundamental factor (Brownmiller et al., 2008). Our results are consistent with the assumption of Hidalgo et al. (2009), that low temperature fruit storage would preserve antioxidant capacity thanks to a higher free radical scavenging DPPH values than at room temperature).

Data for fruit colour and firmness of the genotypes tested are presented in Tables 2, 3 and 4. 'Candonga Sabrosa' and 'PA1' produced fruits with lighter colour than the other genotypes (39.56 and $39.3 \mathrm{~L}^{*}$, respectively), while 'Sant Andreas' produced the darkest fruit $\left(36.8 \mathrm{~L}^{*}\right)$. In addition, fruits of 'Sabrina' and 'Candonga Sabrosa' showed higher Chroma values (46.8 and 46.0, respectively), than the other genotypes; thus resulting in a more vivid and less greenish colour (lower hue angle). Significant differences were detected in skin colour parameters between the two storage temperatures (Tables 2 and 3 ). $L^{*}$ value is a useful indicator of fruit darkening during storage, either due to oxidative browning reactions or to increasing pigment concentrations. According to our results, $L^{*}$ value decreased during storage at $20{ }^{\circ} \mathrm{C}$. This resulted in fruit of darker colour. Strawberries stored at $4^{\circ} \mathrm{C}$ had a more intense colour (higher Chroma) than 
14

those stored at $20^{\circ} \mathrm{C}$ (Table 3), This could be due either to ripening inhibition or to discoloration of strawberries during storage at high temperature. Regardless of the genotype tested, the superficial red colour of the fruits as measured by $\mathrm{a}^{*}$ value increased during storage at $4{ }^{\circ} \mathrm{C}$ (Table 3), whereas the Hue ${ }^{\circ}$ angle decreased during storage. The highest decrease in the Hue ${ }^{\circ}$ value was observed in fruits stored at $4{ }^{\circ} \mathrm{C}$ as compared to those stored at $20^{\circ} \mathrm{C}$. 'Candonga Sabrosa', 'PA1' and 'PA2' fruits tended to be darker (lower Hue ${ }^{\circ}$ values) than the other genotypes. ANOVA for $\mathrm{b}^{*}$, and $\mathrm{Hue}^{\circ}$ colour parameters showed a significant effect of the interaction $\mathrm{G} \times \mathrm{S}$. Colour in fresh strawberries is a fundamental quality factor considered by consumers. The colour development rate of strawberry increased with increasing maturation. Decreases in $\mathrm{L}^{*}$ value of strawberry fruits have previously been reported by others researches (Almenar et al., 2007; Harker et al., 2000). However, in our study, strawberry fruits stored at $4{ }^{\circ} \mathrm{C}$ tended to be brighter (higher $\mathrm{L}^{*}$ value) This, according to Nunes et al., 2005, might be due to greater water loss and associated browning during storage at $20^{\circ} \mathrm{C}$. The $\mathrm{a}^{*}$ value increased significantly in fruits stored at $4^{\circ} \mathrm{C}$, This response could be related to the accumulation of anthocyanin pigments and high degree of red fruits.

Regardless of the storage temperature treatment, 'Candonga Sabrosa' showed the highest firmness $(8.8 \mathrm{~N})$ followed by 'PA2' and 'Florida Fortuna' (8.2 and $8.1 \mathrm{~N}$, respectively) which in turn showed a significant higher firmness than 'Sabrina', 'PAl' and 'Sant Andreas' (7.4 and 6.2 N, respectively). Firmness in fruits stored at $4{ }^{\circ} \mathrm{C}$, averaged over genotypes was significantly higher than in fruits stored at $20^{\circ} \mathrm{C}$. Data for firmness showed a significant effect of the interaction $G \times S$ (Tables 2 and 4) with the highest figure in the combination 'Candonga Sabrosa' either with fruit storage at 4 ${ }^{\circ} \mathrm{C}$ or at $20{ }^{\circ} \mathrm{C}$ and the lowest in the combination 'Sant Andreas' $\times$ fruit storage at $20{ }^{\circ} \mathrm{C}$. It is known that the mechanical properties of fruits are related to firmness and, depend on cell wall strength, cell-to-cell adhesion, cell packing and the internal pressure or turgor of cells (Nunes et al., 2005). Softening of strawberry fruits during storage is mainly due to loss of cell wall material, which is more pronounced in the cortical tissue than in the pith tissue (Koh et al., 1997). According to our results 'Candonga Sabrosa' represent an interesting choice in terms of transportation requirements because of its higher resistance to physical injury and abrasion.

\section{Molecular characterization}

The genetic characterization of the six genotypes was conducted considering all detected peaks. In case they were differing of only one base, they were considered different alleles of the same marker. The UGMA dendrogram (Fig. 2) showed that 'Sabrina' and 'Sant Andreas' cultivars were highly similar. 'Candonga Sabrosa' and 'Florida Fortuna' cultivars were also closely related and similar to 'PA2'. No amplification products were observed for 'PA1' and no peaks were detected for any of the five analysed markers. Therefore it was not possible to identify the genetic distance with the other genotypes. The SSR analysis allowed differentiating clearly the genotypes under study (Table 5). It was possible to divide the five markers in two groups: the first one clustering the three SSRs (A01, A02, and A03 showing high polymorphism) and the second group including a monomorphic SSR A05 and the SSR A04 that allowed differentiating just genotype 'Florida Fortuna' while it recognizes as similar the resting four genotypes. Just three SSR are enough on their own to separate the 5 genotypes while the other two markers do not add any further information. SSR A02 and SSR A03 amplify always more than 2 loci for each genotype. Three loci are amplified also by SSR A04 but just in 'Florida Fortuna' cultivar. More than three loci, six alleles are evidenced in 'Florida Fortuna', are amplified also by SSR A01 with just the single exception of genotype 'PA2'. Working with plant species, it is frequently reported the presence of inhibitors, usually secondary metabolites (polyphenols, tannins, polysaccharides), that can hinders the activity of the polymerases. The adding of substances able to remove inhibitors is frequently cited as a possible solution to this problem. Despite we tried by adding substances like PVP, listed in literature as working in improving of DNA amplificability, we did not obtain any amplification for genotype 'PAl'. At the moment we do not have any explanation to this fact, also considering that with the other genotypes we did not have any problem. The polyploid nature of the samples is confirmed by

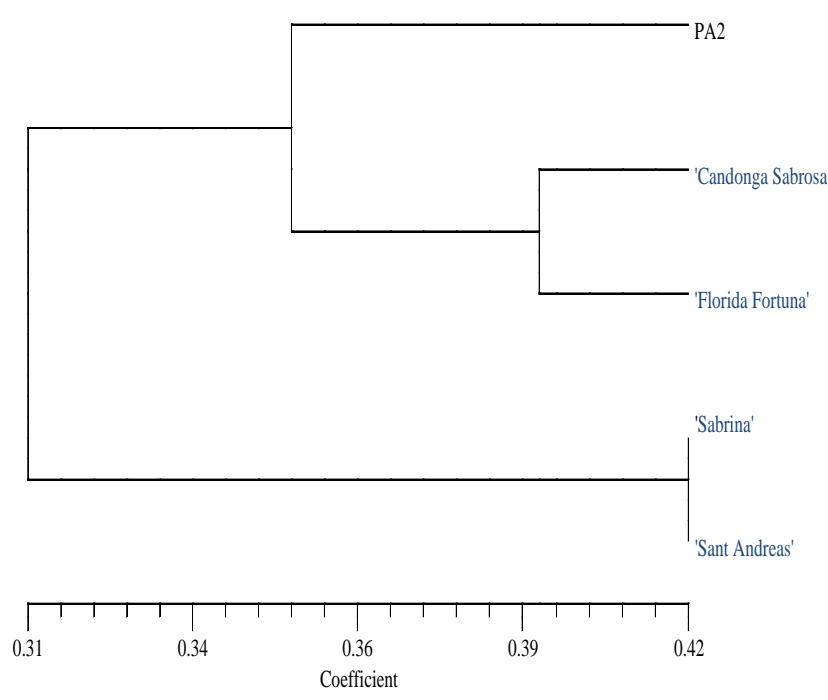

Fig. 2. Dendrogram showing the genetic relatedness of 5 strawberry genotypes based on the UPGMA cluster analysis of five simple sequence repeat marker data

Table 5. Genetic profile of the different genotypes with the five SSR markers used

\begin{tabular}{|c|c|c|c|c|c|c|}
\hline & \multirow{2}{*}{ SSR } & \multicolumn{5}{|c|}{ Genotypes } \\
\hline & & 'PA2' & 'Candonga Sabrosa' & 'Florida Fortuna' & 'Sabrina' & 'Sant Andreas' \\
\hline \multirow{5}{*}{ SSR } & A01 & $158^{\mathrm{a}}$ & $179-171-164-162-158$ & $182-180-178-171-164-158$ & $182-179-164-158$ & $179-164-162-158$ \\
\hline & A02 & $152-150-148-146-142$ & $150-148-140$ & $152-150-142$ & $152-146$ & $150-148-140$ \\
\hline & A03 & $167-158-154-150-148$ & $160-158-154-150$ & $158-156-152-150-148$ & $158-156-154-150-148$ & $158-156-154-150-148$ \\
\hline & A04 & $118-114$ & $118-114$ & $133-118-114$ & $118-114$ & $118-114$ \\
\hline & A05 & $219-211$ & $219-211$ & $219-211$ & $219-211$ & $219-211$ \\
\hline
\end{tabular}

${ }^{a}$ Size of the alleles in base pairs 
the fact that three different markers (A01, A02 and A03) were able to amplify several loci inside the single individuals. 'PA2' line with SSR A01 seems to amplify just a single allele but, considering that with the other markers, it amplifies more than a single allele, it is likely that this situation can be more a consequence of the failure of the amplification of other alleles (null alleles) than the consequence of a true homozygosity in the polyploidy genome for this locus. The absence of any peaks and amplification products for genotype 'PAl' may be explained by its hybrid nature that renders sometimes possible the failure of amplificated markers. It is also possible that null alleles may be present for all the five markers.

\section{Conclusions}

Strawberry breeding activity in Mediterranean environments is nowadays aimed to select new genotypes characterized by early fruit ripening, adapted to fresh plant plantations, and characterized by a longer postharvest life (D'Anna et al., 2014a). Our results confirmed the high yield and quality characteristics of 'Florida Fortuna'. However, it was also shown that the new line 'PA2', might deserve attention by growers involved in strawberry early fruit production in Mediterranean areas. 'Candonga Sabrosa', although less early and productive than 'Florida Fortuna' and 'PA2', showed a high level of fruit quality and firmness. The new lines 'PAl' and 'PA2' demonstrated satisfying results in terms of both agronomic and quality parameters. They also showed significant fractions of biologically active compounds such as total soluble solids, ascorbic acid, antioxidant capacity, total anthocyanins and phenols. In particular, ascorbic acid, which was higher in 'PA2' as compared to the other genotypes, is one of the most important nutritional quality factors in horticultural crops and it has many biological activities in the human body. Furthermore, our data indicate that a $4^{\circ} \mathrm{C}$ fruit storage temperature treatment for 36 hours positively affected the physical and chemical quality properties of strawberry fruits, whereas overall fruit quality declined at $20^{\circ} \mathrm{C}$ storage. In particular, as the storage temperature increased, strawberries showed a significant decrease of ascorbic acid, phenolic compounds, antioxidant capacity, redness $\left(\mathrm{a}^{*}\right)$, lightness $\left(\mathrm{L}^{*}\right)$, and colour saturation (Chroma). In general, storage of strawberries at $4{ }^{\circ} \mathrm{C}$ delayed fruit softening and maintained better colour than at $20{ }^{\circ} \mathrm{C}$. As regard as the genetic characterization, although the analysis was limited to a reduced number of different genotypes, it resulted that 'PA2' was closely related to 'Candonga Sabrosa' and 'Florida Fortuna'.

\section{References}

Almenar E, Del-Valle V, Hernández-Muñoz P, Lagarón JM, Catalá R, Gavara R (2007). Equilibrium modified atmosphere packaging of wild strawberries. Joumal of the Science of Food and Agriculture 87:1931-1939.

Brand-Williams W, Cuvelier ME, Berset C (1995). Use of a Free Radical Method to Evaluate Antioxidant Activity. Lebensmittel-Wissenschaft \&Technologie 28:25-30.

Brownmiller C, Howard LR, Prior RL (2008). Processing and storage effects on monomeric anthocyanins, percent polymeric color, and antioxidant capacity of processed blueberry products. Journal of Food Science 73:H72-H79.
Cocco C, Magnani S, Maltoni ML, Quacquarelli I, Cacchi M, Corrêa Antunes LE, D'Antuono LF, Faedi W, Baruzzi G (2015). Effects of site and genotype on strawberry fruits quality traits and bioactive compounds. Journal of Berry Research 5:145-155.

Cordenunsi BR, Nascimento JRO, Lajolo FM (2003). Physico-chemical changes related to quality of five strawberry fruit cultivars during coolstorage. Food Chemistry 83(2):167-173.

D’Anna F, Caracciolo G, Prinzivalli C, Faedi W, Baruzzi G, Sbrighi P (2014)a. Update on the Sicilian strawberry breeding project. Acta Horticulturae 1049:873-876.

D’Anna F, Caracciolo G, Alessandro R, Faedi W (2014). Effects of Plant type on two strawberry cultivars in Sicily. Acta Horticulturae 1049:553556.

D’Anna F, Iapichino G (2002). Effects of runner order on strawberry plug plant fruit production. Acta Horticulturae 567:301-303.

D’Anna F, Prinzivalli C, Caracciolo G, Moncada A, Vetrano F, Baruzzi G, Faedi W (2009). Il miglioramento genetico della fragola in Sicilia [The strawberry genetic improvement in Sicily]. Atti VII Convegno Nazionale: LaFragola Presentee Futuro.

D’Anna F, Prinzivalli C, Pappalardo G, Camerata Scovazzo G, Moncada A, Giovino A (2005). Cultivar e selezioni di Fragola per le aree meridionali [Cultivars and lines of strawberry suitable to the Mediterranean areas]. L'informatore Agrario 2:45-50.

D'Anna F, Sabatino L (2013). Morphological and agronomical characterization of eggplant genetic resources from the Sicily area. Journal of Food, Agriculture \& Environment 11:401-404.

Duvic DN (1977). Genetic rates of gain in hybrid maize during the past 40 years. Maydica 22:187-196.

Foo LY, Porter LJ (1981). The structure of tannins of some edible fruits. Journal of the Science of Food and Agriculture 32:711-716.

Gil MI, Holcroft DM, Kader AA (1997). Changes is strawberry anthocyanins and other polyphenols in response to carbon dioxide treatments. Journal of Agricultural and Food Chemistry 45(5):16621667.

Green A (1971). Soft fruits. In: Hulme AC (Ed). The Biochemistry of Fruits and Their Products. Academic Press, London, UK2:375-410.

Han C,Lederer C, McDaniel M,Zhao Y (2005). Sensory evaluation of fresh strawberries (Fragaria ananassa) coated with chitosan-based edible coatings. Journal of Food Science 70(3):S172-S178.

Han C,Zhao Y,Leonard SW, Traber M (2004). Edible coatings to improve storability and enhance nutritional value of fresh and frozen strawberries (Fragaria $\times$ ananassa) and raspberries (Rubus ideaus). Postharvest Biology and Technology 33:67-78.

Hancock JF (1999). The strawberry species. In: Strawberries. CABI Publishing, Cambridge, Massachusetts, USA.

Harker FR, Elgar HJ, Watkins CB, Jackson PJ, Hallett IC (2000). Physical and mechanical changes in strawberry fruit after high carbon dioxide treatments. Postharvest Biology and Technology 19:139-146.

Harris CM, HarveyJM(1973). Quality and decay of California strawberries stored in carbon dioxide-enriched atmospheres. Plant Disease 57:44-46.

Hidalgo A, Brandolini A, Pompei C (2009). Kinetics of tocols degradation during the storage of einkorn (Triticum monococcum L. ssp. monococcum) and breadwheat (Triticum aestivum L. ssp. aestivum) flours. Food Chemistry 116:821-827. 
16

Koh TH, Melton LD, Newman RH (1997). Solid-state ${ }^{13} \mathrm{C}$ NMR characterization of cell walls of ripening strawberries. Canadian Journal of Botany 75:1957-1964.

Larsen M, Watkins CB (1995). Firmness and acetaldehyde, ethyl acetate and ethanol in strawberries stored in controlled and modified atmospheres. Postharvest Biology and Technology 5:39-50.

Lila MA (2004). Anthocyanins and Human Health: An In Vitro Investigative Approach. Journal of Biomedicine and Biotechnology 5:306-313.

Mercantilia (1989). Guide to Food Transport Fruit and Vegetables. Mercantilia Publishers, Copenhagen, $247 \mathrm{p}$.

Manning K (1996). Soft fruits. In: Seymour GB, Taylor JE, Tucker GA (Eds). Biochemistry of Fruit Ripening. Chapman \& Hall, London, UK pp 347-373.

Miceli A, Sabatino L, Moncada A, Vetrano F, D’Anna F (2014). Nursery and field evaluation of eggplant grafted onto unrooted cuttings of Solanum torvum Sw.Scientia Horticulturae 178:203-210.

Nunes MCN, Brecht JKA, Morais MMB, Sargent SA (2005). Possible influences of water loss and polyphenol oxidase activity on anthocyanin content and discoloration in fresh ripe strawberry (cv. Osogrande) duringstorage at $1{ }^{\circ} \mathrm{C}$. Journal of Food Science 70(1):79-84.

Patthamakanokporn O, Puwastien P, Nitithamyong A, Sirichakwal PP (2008). Changes of antioxidant activity and total phenolic compounds during storage of selected fruits. Journal of Food Composition and Analysis 21:241-248.

Pelayo C, Ebeler SE, Kader AA (2003). Postharvest life and flavor quality of three strawberry cultivars kept at $5{ }^{\circ} \mathrm{C}$ in air or air $+20 \mathrm{kPa} \mathrm{CO}_{2}$. Postharvest Biology and Technology 27(2):171-183.

Rabino I, Mancinell A (1986). Light, temperature, and anthocyanins production.Journal of Plant Physiology 81:922-924.

Russell WA (1984). Agronomic performance of maize cultivars representing differenteras of breeding. Maydica 29:375-390.

Sabatino L, Palazzolo E, D’Anna F (2013). Grafting suitability of Sicilian eggplant ecotypes onto Solanum torrum: Fruit composition, production and phenology. Journal of Food, Agriculture and Environment 11:1195-1200.
Sanz C, Perez AG, Olias R, Olias JM (1999). Quality of strawberries packed with perforated polypropylene.Journal of Food Science 64(4):748-752.

Shaw DV, Larson KD (2008). Performance of early-generation and modern strawberry cultivars from the University of California breeding programme in growing systems simulating traditional and modern horticulture. Journal of Horticultural Science \& Biotechnology 83:648652.

Slinkard K, Singleton VL (1997). Total phenol analysis: Automation and comparison with manual methods. American Journal of Enology and Viticulture 28:49-55.

Smith RB (1992). Controlled atmosphere storage of 'Redcoat' strawberry fruit. Journal of the American Society for Horticultural Science 117:260-264.

Sorrenti V, Salerno L, Di Giacomo C, Acquaviva R, Siracusa MA, Vanella A (2006). Imidazole derivatives as antioxidants and selective inhibitors of nNOS. Nitric Oxide 14:45-50.

Tomás-Barberán FA, Espín JC (2001). Phenolic compounds and related enzymes as determinants of quality in fruits and vegetables. Journal of the Science of Food and Agriculture 81:853-876.

Troyer AF (1990). A retrospective of corn genetic resources. Journal of Heredity 81:17-24.

Wang Q, Tao S, Dubé C, Tury E, Hao YJ, Zhang S, Zhao M, Wul W, Khanizadeh S (2012). Postharvest Changes in the Total Phenolic Content, Antioxidant Capacity and L-Phenylalanine Ammonia-Lyase Activity of Strawberries Inoculated with Botrytis cinerea. Journal of Plant Studies 1(2):11-18.

Wicklund T, Rosenfeld HJ, Martinsen BK, Sundfor MW, Lea P, Bruun T, BlomhoffR, Haffner K (2005). Antioxidant activity capacity and colour of strawberry jam as influenced by cultivar and storage conditions. Journal of Food Science and Technology 38:387-391.

Yoon MY, Moe KT, Kim DY, Rho IR, Kim S, Kim KT, Won MK, ChungJW, Park YJ (2012). Genetic diversity and population structure analysis of strawberry (Fragaria $\times$ ananassa Duch.) using SSR markers. Electronic Journal of Biotechnology 15(2):1-16. 